\title{
A Taxonomy Proposal for the Assessment of the Changes in Soundscape Resulting from the COVID-19 Lockdown
}

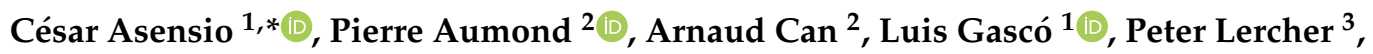 \\ Jean-Marc Wunderli ${ }^{4}{ }^{\mathbb{D}}$, Catherine Lavandier ${ }^{5}$, Guillermo de Arcas ${ }^{1}{ }^{\mathbb{D}}$, Carlos Ribeiro ${ }^{6}$, \\ Patricio Muñoz ${ }^{7}$ and Gaetano Licitra ${ }^{8, *(D)}$ \\ 1 Instrumentation and Applied Acoustics Research group (I2A2), Universidad Politécnica de Madrid, \\ 28031 Madrid, Spain; luisgascosanchez@gmail.com (L.G.); g.dearcas@upm.es (G.d.A.) \\ 2 UMRAE, Univ Gustave Eiffel, IFSTTAR, CEREMA, 44340 Bouguenais, France; \\ pierre.aumond@univ-eiffel.fr (P.A.); arnaud.can@ifsttar.fr (A.C.) \\ 3 Institute for Highway Engineering and Transport Planning, Graz University of Technology, \\ 8010 Graz, Austria; peter.lercher.at@gmail.com \\ 4 Empa, Swiss Federal Laboratories for Material Science and Technology, Laboratory for Acoustics/Noise \\ Control, 8600 Dübendorf, Switzerland; jean-marc.wunderli@empa.ch \\ 5 ETIS Laboratory, UMR 8051, CY Cergy Paris University, ENSEA, CNRS, \\ F-95302 Cergy-Pontoise Cedex, France; catherine.lavandier@cyu.fr \\ 6 Bruitparif, 93200 Saint-Denis, France; Carlos.Ribeiro@bruitparif.fr \\ 7 Acoucite, Observatoire de l'environnement sonore de la Métropole de Lyon, 69007 Lyon, France; \\ patricio.munoz@acoucite.org \\ 8 Environmental Protection Agency of Tuscany Region, Pisa Department, 56127 Pisa, Italy \\ * Correspondence: casensio@i2a2.upm.es (C.A.); g.licitra@arpat.toscana.it (G.L.)
}

Received: 16 May 2020; Accepted: 5 June 2020; Published: 12 June 2020

\begin{abstract}
Many countries around the world have chosen lockdown and restrictions on people's mobility as the main strategies to combat the COVID-19 pandemic. These actions have significantly affected environmental noise and modified urban soundscapes, opening up an unprecedented opportunity for research in the field. In order to enable these investigations to be carried out in a more harmonized and consistent manner, this paper makes a proposal for a set of indicators that will enable to address the challenge from a number of different approaches. It proposes a minimum set of basic energetic indicators, and the taxonomy that will allow their communication and reporting. In addition, an extended set of descriptors is outlined which better enables the application of more novel approaches to the evaluation of the effect of this new soundscape on people's subjective perception.
\end{abstract}

Keywords: COVID-19; noise; soundscape; metrics; indicators; descriptors; sound; lockdown

\section{Introduction}

Unfortunately, the year 2020 will be known as the year of the coronavirus disease (COVID-19) pandemic. To a greater or lesser extent, the epidemic has spread to every continent, without distinction, affects all ages and is particularly dangerous for older people. The strategies designed by different governments to combat the pandemic in many countries have been very diverse, but many countries have chosen lockdown and restrictions on people's mobility [1]. More than 3.9 billion people, or a half of the world's population living in 90 different countries around the world have been under containment as a measure to maintain social distancing [2]. 
Commercial flights, both international and domestic, have been severely restricted, with all flights not dedicated to the provision of medical supplies and other essential products being affected in many countries [3]. Likewise, ground transportation has also been severely restricted, with substantial percentages of the population unable to access their jobs or having to work remotely [4].

In addition to the dreadful consequences that the pandemic has had on the population, in terms of infections, hospitalizations and the number of deaths, the lockdown of people and their absence from the environment has had considerable environmental consequences, with animal species returning to the urban environment and beaches, and varying reductions in peak and average air pollution levels in populated areas [5-7].

As a result of restrictions on urban mobility, traffic noise has been drastically reduced. Conversely, natural noise, such as bird singing, is emerging again, although it is difficult to know whether this is related to a closer presence of the source, an increase in levels, lack of masking noise or a perceptual effect, and whether it is due to the lockdown or not [8].

Therefore, the acoustics community has been mobilized. National acoustical associations in Italy and UK launched initiatives to collect measurement campaign data $[9,10]$ and many consultants, engineers, research groups and noise management authorities around the world have begun to produce reports to address, through measurement data, the assessment of the reduction that confinement has produced in the environmental noise of each city. Although a few of the initiatives gave some general indications, there is a risk that these interesting reports, coming from personal and structured actions, suffer from a lack of consistency that makes it almost impossible to compare them, which would be extremely challenging for the overall analysis of the effect on the confinement on human behaviors and perception.

At the same time, new projects are active to collect recordings and metadata of sounds in the COVID-19 scenario, such as the LYS (locate your sound) project [11] in Italy with around 3000 recordings on 6 May 2020, showing the richness of lived experiences and the value of the recordings so that people do not forget and recover lost sounds. Also, through sound recording and automatic audio tagging of recordings, the Silent-Cities Project aims to create a database of audio files that allows to study, among other things, the relationship between natural and human-generated sounds in different levels of economic activity [12]. Also related to this topic, Acoucité has developed a questionnaire oriented towards assessing population feelings about the changes in the noise environment since lockdown [13].

Since it is expected that in the coming months these preliminary analyses will become scientific articles, it is considered very necessary to establish a common framework to harmonize the basic results of these investigations, so that comparisons can be made between different populations and countries, leading to a macro-analysis that will make it possible to know and evaluate the overall effect of confinement, to compare the effect of different confinement strategies and to communicate this information to the public.

In order to achieve these objectives, in this communication we propose a minimum set of common descriptors, which will make it possible to assess noise pollution in each location, and to appraise the noise reduction that the measures against COVID-19 imply. In addition, to give a status of open data to all this information, and to facilitate future analyses, we propose a data structure that gathers all the noise-related data information in the form of a taxonomy. Although this data structure arises as a necessity for the comparison of noise studies related to COVID-19 effects, it should also be valid for the assessment of noise in the future, with minor changes both in exceptional and everyday circumstances.

\section{Noise Descriptors and Taxonomy for Physical Characterization}

This paper focuses on indicators for physical characterization of noise, since an important part of the analysis will probably deal with the pre-post comparison based on the noise monitoring systems implemented in cities and airports. Indicators that aim to assess people's exposure to noise are widespread [14]. With their benefits and shortcomings, they allow a description to be made based on objective criteria, such as the acoustic energy contained in the environment. 


\subsection{Measurement Data Structure}

We recommend that each measurement be described by the following set of data, which will refer to a time interval starting at the day and time referenced. We propose to use a simple open file format such as the comma-separated values (CSV) file to share the raw data. The field names of the first row of the dataset are shown in Table 1, and each row of the file will describe a measurement.

It is recommended that in each location, the basic data set reported on a daily basis be $L_{n}$ and $L_{d e n}$, following the recommendations of the Environmental Noise Directive [15]. Additionally, it is considered convenient to add, if available, as an extended data set, the time series of measurements of equivalent

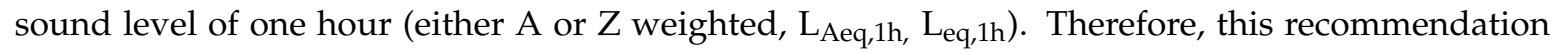
includes 24 descriptors a day $\left(24 \mathrm{~L}_{\mathrm{Aq}, 1 \mathrm{~h}}\right.$ or $\mathrm{L}_{\mathrm{eq}, 1 \mathrm{~h}}$ values). The same data structure can be valid for daily or hourly basis, using the time of indicator definition, duration and starting time.

Table 1. Measurement data structure.

\begin{tabular}{|c|c|c|}
\hline Field & Description & Data Type \\
\hline Identification & $\begin{array}{c}\text { Short name, to identify the measurement } \\
\text { location }\end{array}$ & String \\
\hline City & City & String \\
\hline Country & Country & String \\
\hline Measurement provider & $\begin{array}{l}\text { Entity that is providing the measurements } \\
\text { (i.e., local authority or airport manager) }\end{array}$ & String \\
\hline Coordinates & Measurement location, WGS84 format & $\begin{array}{c}\text { String } \\
\text { latitude, longitude } \\
\text { “48.856614; } 2.3522219 "\end{array}$ \\
\hline Instrument class & $\begin{array}{l}\text { Certified instruments should be considered, } \\
\text { either type } 1 \text { or } 2 \text {. } \\
\text { Non-certified (but calibrated) sensors, type } 3\end{array}$ & Integer $(1,2,3)$ \\
\hline Instrument brand & Type of area (residential, hospital, school, ...) & String \\
\hline Prevailing sound sources & $\begin{array}{l}\text { Semicolon delimited tags to describe the area, } \\
\text { showing the prevailing sound sources }\end{array}$ & String (road, air, rail, nightlife, etc.) \\
\hline Date/Time & Measurement starting date and o'clock time & $\begin{array}{c}\text { String } \\
\text { YYYYmmddThh0000 }\end{array}$ \\
\hline Stage & $\begin{array}{l}\text { Before lockdown }=1 \\
\text { Lockdown }=2 \\
\text { After lockdown }=3\end{array}$ & Integer $(1,2,3)$ \\
\hline Description of the stage & $\begin{array}{l}\text { A qualitative description of the period to } \\
\text { analyze. It will be used to understand the } \\
\text { level of lockdown in the city where the } \\
\text { measurements were taken. Some tags } \\
\text { are proposed. }\end{array}$ & $\begin{array}{l}\text { String. Using tags: (a) events } \\
\text { suspended; (b) schools closed; (c) } \\
\text { non-essential shops closed; (d) } \\
\text { non-essential movement banned; (e) } \\
\text { land border closed; (f) non-essential } \\
\quad \text { production closed [16] }\end{array}$ \\
\hline Duration & $\begin{array}{l}\text { Measurement duration. Only necessary for } \\
\text { indicator type } L_{\text {eq. }}\end{array}$ & Integer (minutes) \\
\hline Indicator & Type of indicator & String $\left(\mathrm{L}_{\mathrm{eq}}, \mathrm{L}_{\mathrm{den}}, \mathrm{L}_{\mathrm{n}} \ldots\right)$ \\
\hline Frequency weighting & Frequency weighting & String $(\mathrm{A}, \mathrm{Z})$ \\
\hline Measurement & The value of the indicator & Float, 1 decimal digit (decibel) \\
\hline Miscellaneous & Free comment about the data collection & String \\
\hline
\end{tabular}

It is necessary to ensure the reliability of the data, so that measurements that could be affected by weather, maintenance operations or unusual sound events, that could affect the measurements, are excluded.

Table S1, provided as supplementary material, contains an example of a data file, according to this measurement data structure. 


\subsection{Data to Report}

For data processing and reporting, local diversities and uses may result in large differences that prevent comparison of results. Each study can have a very different scope and objectives, and thus the results reported can vary considerably. However, we consider that analyzing the reduction of noise produced during lockdown may be an objective common to all of them, and, focusing on the evaluation of such reduction, we propose a series of indicators that may be useful, considering them as a set of minimums that all studies should address. For this reason, we recommend that the reports contain, at least, a time series (chart or table) for $L_{d e n}$ and $L_{n}$, and the information specified in Table 2:

Table 2. Minimums to report.

\begin{tabular}{|c|c|c|c|c|}
\hline \multirow[t]{2}{*}{$\begin{array}{l}\text { Measurement } \\
\text { Location: }\end{array}$} & \multirow[t]{2}{*}{ Identification } & \multicolumn{3}{|c|}{ STAGE } \\
\hline & & Before & Lockdown & After \\
\hline \multirow{6}{*}{ Working day } & $\%$ days exceeding $L_{\text {den }}=65$ & & & \\
\hline & $\%$ days exceeding $L_{n}=55$ & & & \\
\hline & Average $\mathrm{L}_{\mathrm{Aeq}, 1 \mathrm{~h}}$ during rush hour (dBA) & & & \\
\hline & Average $\mathrm{L}_{\mathrm{Aeq}, 1 \mathrm{~h}}$ during off-peak hour (dBA) & & & \\
\hline & Average $\mathrm{L}_{\mathrm{den}}(\mathrm{dBA})$ & & & \\
\hline & Average $\mathrm{L}_{\mathrm{n}}(\mathrm{dBA})$ & & & \\
\hline
\end{tabular}

Notes: Arithmetic averages must be considered. The "Before" stage is the one that determines rush and off-peak hour. It will be different for working days and weekends.

In some locations, due to their characteristics, it may be of interest to evaluate the reduction occurring during weekends or holidays. In this case, the information contained in Table 2 can be replicated, redefining the peak and valley hours, depending on the prevailing noise source in each area.

\subsection{Data Collection}

Although data collection is out of the scope of this communication, we encourage providers to share their database with the community on the Zenodo platform, which is an open-access repository operated by CERN [17]. For each submission, a persistent digital object identifier (DOI) is given, which makes the stored items easily citable. The upload limit is about 50 GB. To identify all the databases that will have followed the protocol recommended in this communication. Please add the tags: "Noise", "COVID-19"; “Lockdown”, “Taxonomy".

\section{Extended Indicators}

The previous section focuses on describing the noise dose, and how it has decreased because of the reduced mobility and human activities that confinement has produced. This is an aspect that has been well studied over decades, so it has been relatively easy to agree on a set of data, which we believe noise monitoring systems will be recording on a regular basis.

However, this set of indicators does not fully describe the subjective experience that the new soundscape draws. Sudden shift in sound environments include changes in noise dynamics, and the emergence of unusual sound sources. Beyond the purely energetic effect that derives from the confinement, it is foreseeable that the perception of change in the soundscape will be different according to cultural aspects $[18,19]$. This can only be widely investigated if an adequate set of descriptors, conveniently harmonized at international level, are defined. This requires an extended set of indicators needed for more detailed analyses.

These types of investigations are not so widespread in the different areas of noise management in public administrations, and therefore there are restrictions with respect to the technical knowledge 
of the staff who must carry out the measurements. This is the reason why we wanted to include a classification of indicators in this paper, that may be helpful for future research, and which may still be used to describe outdoor sound in the face of the unique phenomenon we are experiencing, from different points of view, such as biophony or soundscape.

Table 3 also includes the energetic indicators already mentioned in the previous section, to give consistency, and to allow comparison of the different types of noise descriptors. The following indicators should be calculated on an hourly basis.

Table 3. Extended indicators.

\begin{tabular}{|c|c|c|c|}
\hline & Indicators and Description & Physical Descriptive Power & Perceptive Descriptive Power \\
\hline $\begin{array}{l}\text { Energetic } \\
\text { indicators }\end{array}$ & $\begin{array}{l}\mathrm{L}_{\text {eqT }} \text { continuous equivalent sound } \\
\text { pressure level during time period } \mathrm{T} \\
\mathrm{L}_{\mathrm{n}} \text { continuous equivalent sound } \\
\text { pressure level during night period } \\
\mathrm{L}_{\mathrm{den}} \text {, day, evening, night combined } \\
\text { indicator [20-22] }\end{array}$ & $\begin{array}{l}\text { Cumulative energetic } \\
\text { indicators. A, C or Z } \\
\text { frequency weighting }\end{array}$ & $\begin{array}{l}\text { Correlated to long term health } \\
\text { effects }\end{array}$ \\
\hline \multirow{3}{*}{$\begin{array}{l}\text { Statistical } \\
\text { indicators }\end{array}$} & $\mathrm{L}_{90}[23], 90 \%$ percentile level & Describes background noise & Does not emerge from studies \\
\hline & $\mathrm{L}_{50}, 50 \%$ percentile level $[24]$ & $\begin{array}{l}\text { Good for discriminating } \\
\text { sound environments }\end{array}$ & $\begin{array}{l}\text { Very good correlation with } \\
\text { perceived sound intensity and } \\
\text { sound pleasantness }\end{array}$ \\
\hline & $\mathrm{L}_{10}, 10 \%$ percentile level $[23-25]$ & $\begin{array}{l}\text { Describes contribution of } \\
\text { loudest events }\end{array}$ & $\begin{array}{l}\text { Outperforms } \mathrm{L}_{\mathrm{Aeq}} \text { to describe } \\
\text { perception of high noise levels }\end{array}$ \\
\hline \multirow{4}{*}{$\begin{array}{l}\text { Spectrum and } \\
\text { source related } \\
\text { indicators }\end{array}$} & $\begin{array}{l}\text { Sound ecology indicators: NDSI, } \\
\text { normalized difference soundscape } \\
\text { index; ACI, acoustic complexity in; } \\
\text { entropy; BIO, bioacoustic index; } \\
\text { ADI, acoustic diversity index; AEI, } \\
\text { acoustic evenness index }[11,26]\end{array}$ & $\begin{array}{l}\text { Good for discriminating } \\
\text { presence of biophonic sounds } \\
\text { and anthropogenic sounds in } \\
\text { urban sound }\end{array}$ & $\begin{array}{l}\text { Likely to be correlated with the } \\
\text { time presence of the described } \\
\text { sound sources }\end{array}$ \\
\hline & $\begin{array}{l}\text { The normalized time and frequency } \\
\text { second derivative: } \\
\text { TFSD } \text { mean, } 4 \mathrm{k} \mathrm{Hz} \text { (birds); } \\
\text { TFSD }_{\text {mean, } 500 \mathrm{~Hz} \text { (human voices) }} \\
{[27,28]}\end{array}$ & $\begin{array}{l}\text { Can be computed from octave } \\
\text { band } 1 \mathrm{~s} \text { dataset. Good for } \\
\text { discriminating presence of } \\
\text { biophonic sounds and } \\
\text { anthropogenic sounds in } \\
\text { urban sound environment }\end{array}$ & $\begin{array}{l}\text { Likely to be correlated with the } \\
\text { time presence of the described } \\
\text { sound sources }\end{array}$ \\
\hline & $\begin{array}{c}\mathrm{L}_{\mathrm{eq}}(63 \mathrm{~Hz}-500 \mathrm{~Hz}) ; 1 / 3 \text { octave band } \\
\text { continuous sound pressure level } \\
{[28,29]}\end{array}$ & $\begin{array}{l}\text { Good for discriminating } \\
\text { sound environments } \\
\text { frequency content }\end{array}$ & $\begin{array}{c}\text { Correlated with the time presence } \\
\text { of Traffic }\end{array}$ \\
\hline & $\begin{array}{c}\mathrm{L}_{\mathrm{Ceq}}-\mathrm{L}_{\mathrm{Aeq}} \text {, difference between A- } \\
\text { and C-weighted equivalent } \\
\text { continuous sound levels [30-34] }\end{array}$ & $\begin{array}{l}\text { Describes the amount of low } \\
\text { frequencies }\end{array}$ & $\begin{array}{l}\text { Differences of } 15 \text { to } 20 \mathrm{~dB} \text { show an } \\
\text { effect on annoyance and } \\
\text { perception of vibrations }\end{array}$ \\
\hline \multirow{3}{*}{$\begin{array}{l}\text { Emergences } \\
\text { and noise } \\
\text { variation } \\
\text { indicators }\end{array}$} & $\begin{array}{c}\mathrm{L}_{\text {Amax }} \text { maximum A-weighted noise } \\
\text { level; NA, number of events above a } \\
\text { threshold; time above a threshold } \\
{[35,36]}\end{array}$ & $\begin{array}{l}\text { NA80, number of events } \\
\text { above a } 80 \mathrm{dBA} \text {, or TA80 time } \\
\text { above } 80 \mathrm{dBA} \text { (additional } \\
\text { thresholds can be considered) }\end{array}$ & $\begin{array}{c}\text { Awakening probability with } \\
\text { increasing } L_{\text {Amax }} \\
\text { The number of high noise level } \\
\text { events may affect sleep motility. } \\
\text { For aircraft noise, also an effect on } \\
\text { annoyance is suggested }\end{array}$ \\
\hline & $\begin{array}{l}\text { Calculated from percentiles. } \\
\text { Fluctuation: defined as the } \\
\text { difference between the (single) } \\
\text { source event and the source } \\
\text { background level. Emergence: } \\
\text { Difference between the source event } \\
\text { and the overall background level } \\
\text { (L10-L90 or L1-L99) [37-42] }\end{array}$ & $\begin{array}{l}\text { Good description of the } \\
\text { energetic increase produced by } \\
\text { a source }\end{array}$ & $\begin{array}{l}\text { Field investigations on annoyance } \\
\text { and hypertension yield some } \\
\text { support in the context of mixed } \\
\text { sound exposure and low } \\
\text { background levels (main roads). } \\
\text { No consensus concerning the } \\
\text { perceptive effects }\end{array}$ \\
\hline & $\begin{array}{l}\text { Intermittency ratio (IR). Ratio } \\
\text { between the sound energy } \\
\text { contributions of events, and the } \\
\text { overall contributions during the } \\
\text { measurement period [43-46] }\end{array}$ & $\begin{array}{l}\text { Expresses the energetic share } \\
\text { of noise exposure created by } \\
\text { individual noise events }\end{array}$ & $\begin{array}{l}\text { Highly intermittent nocturnal } \\
\text { noise is correlated with increased } \\
\text { risk of cardiovascular diseases. In } \\
\text { a fully adjusted hypertension } \\
\text { model the IR made an additional } \\
\text { contribution beyond the } \mathrm{L}_{\mathrm{den}} \text { in } \\
\text { mixed source exposure situations. } \\
\text { IR has an additional effect on } \\
\text { \%HA and can explain shifts of the } \\
\text { exposure-response curve of up to } \\
\text { about } 6 \mathrm{~dB} \text {. }\end{array}$ \\
\hline
\end{tabular}




\section{Conclusions}

The COVID-19 pandemic has significantly modified urban sound environments, opening up an unprecedented opportunity for research in the field. In order to enable these investigations to be carried out in a more harmonized and consistent manner, the group of experts implied in this article agreed on a minimum set of indicators that should imperatively be calculated. Recommendations are also given as concerning the measurement data structure (taxonomy) for the global assessment of the effect that the lockdown due to COVID-19 has produced on environmental noise.

Beyond this minimum, the selection of a set of descriptors that are capable of adequately describing citizens' perception of any new circumstance would be highly desirable, to serve as a guide for future research. For this reason, an overview of an extended set of indicators is presented. These indicators cover all the physical dimensions of sound environments, and are supported by elements of literature: Energetic, spectral and temporal dimension, emergence and source-related indicators. Thus, this extended set of indicators should allow a more detailed analysis of the changes in noise environments related to confinement, and to a broader extent help in understanding the impact on sound environments of any policy achieved at the urban scale.

Finally, the COVID-19 crisis has revealed a big lack in the current state-of-the-art to analyze urban sound environments. The noise indicators mainly deal with sound environments as a whole, and do not distinguish between the sound sources that compose it. The sound environments introduced by the lockdowns modified them not only in levels, but also by the present sources. Natural sounds are heard again, both because there is less noise to mask them, and because of the reappearance of animal species in areas usually occupied by vehicles and people. In these circumstances, even the sounds that were previously integrated to form our acoustic environment now, in isolation, acquire a very particular character, and may be especially relevant. When the passage of a vehicle was hidden by the noise of traffic as a whole, now the movement of each vehicle acquires a whole different meaning. Not to mention other sounds, such as the passing of ambulances, which in the pandemic may intensify their meaning and fully change people's perception.

This dimension is unfortunately absent from current indicators. Therefore, the development of source-orientated indicators, able to quantify the presence of sources of interest, and ideally performing with urban sound mixtures with strong temporal overlaps, is strongly advocated. Premises towards such indicators can be found in the literature, relying on sound recognition [25,47-49].

The physical indicators proposed, although they are linked to perceptual and health effects, will most likely be insufficient to capture the entire sound experience. Sensitive data, such as the speed of the experienced change, the link that can exist between the sound environment and its emotional evocation, the diversity in the life situations of city dwellers faced with the lockdown, cannot be captured by physical indicators. They are, however, still an integral part of the soundscapes during this period. Although emphasized in this specific period, this lack stands for any observed modification in sound environments. This advocates for the collection of sensitive data, in addition to physical data, as part of the next generation of measurement networks [49,50].

Supplementary Materials: The following are available online at http://www.mdpi.com/1660-4601/17/12/4205/s1, Table S1: Data file example.

Author Contributions: Conceptualization, C.A., G.L.; writing original draft preparation, C.A.; state of art: all authors; writing, review, and editing: C.A., G.L., L.G., P.A. A.C., J.-M.W.; review: C.L., P.L., G.d.A., C.R., P.M. All authors have read and agreed to the published version of the manuscript.

Funding: This research received no external funding.

Conflicts of Interest: The authors declare no conflicts of interest. 


\section{References}

1. Aktay, A.; Bavadekar, S.; Cossoul, G.; Davis, J.; Desfontaines, D.; Fabrikant, A.; Gabrilovich, E.; Gadepalli, K.; Gipson, B.; Guevara, M.; et al. Google COVID-19 Community Mobility Reports: Anonymization Process Description (version 1.0). arXiv 2020, arXiv:2004.04145.

2. Coronavirus: Half of Humanity Now on Lockdown as 90 Countries Call for Confinement. Available online: https://www.euronews.com/2020/04/02/coronavirus-in-europe-spain-s-death-toll-hits-10-000-afterrecord-950-new-deaths-in-24-hou (accessed on 13 May 2020).

3. Olive, X.; Strohmeier, M.; Lübbe, J. Crowdsourced air traffic data from The OpenSky Network 2020. OpenAIRE 2020. [CrossRef]

4. Tardivo, A.; Martín, C.S.; Zanuy, A.C. Covid-19 impact in Transport, an essay from the Railways' system research perspective. Pract. Pipeline 2020. Available online: https://advance.sagepub.com/articles/Covid-19_ impact_in_Transport_an_essay_from_the_Railways_system_research_perspective/12204836 (accessed on 15 May 2020). [CrossRef]

5. IQAir. IQAir COVID-19 Air Quality Report; IQAir: Goldach, Switzerland, 2020.

6. Venter, Z.S.; Aunan, K.; Chowdhury, S.; Lelieveld, J. COVID-19 lockdowns cause global air pollution declines with implications for public health risk. medRxiv 2020. Available online: https://www.medrxiv.org/content/ early/2020/04/14/2020.04.10.20060673 (accessed on 15 May 2020). [CrossRef]

7. Monitoring Covid-19 Impacts on Air Pollution. Available online: https://www.eea.europa.eu/themes/air/airquality-and-covid19/monitoring-covid-19-impacts-on (accessed on 13 May 2020).

8. Sounds from the Global Covid-19 Lockdown. Available online: https://citiesandmemory.com/covid19-sounds/ (accessed on 13 May 2020).

9. Grande Partecipazione all'iniziativa AIA di caratterizzazione dei Livelli Sonori Durante l'emergenza da Coronavirus. Available online: https://acustica-aia.it/grande-partecipazione-alliniziativa-aia-di-caratterizzazione-dei-livellisonori-durante-lemergenza-da-coronavirus/ (accessed on 13 May 2020).

10. COVID-19: The Quiet Project-Call for Measurements. Available online: https://www.ioa.org.uk/news/ covid-19-quiet-project-\%E2\%80\%93-call-measurements (accessed on 13 May 2020).

11. Locate Your Sound-Paesaggi Sonori Italiani \#Covid19. Available online: https://locateyoursound.com/en/ (accessed on 13 May 2020).

12. Challéat, S.; Farrugia, N.; Gasc, A.; Froidevaux, J.; Hatlauf, J.; Dziock, F.; Charbonneau, A.; Linossier, J.; Watson, C.; Ullrich, P.A. Silent·Cities. 2020. Available online: osf.io/h285u (accessed on 15 May 2020). [CrossRef]

13. Confinement COVID-19: Impact sur l'environnement Sonore. Available online: http://www.acoucite.org/ confinement-covid-19-impact-sur-lenvironnement-sonore/ (accessed on 13 May 2020).

14. Can, A.; Aumond, P.; Michel, S.; de Coensel, B.; Ribeiro, C.; Botteldooren, D.; Lavandier, C. Comparison of noise indicators in an urban context, Inter-Noise 2016. In Proceedings of the 45th International Congress and Exposition of Noise Control Engineering, Aughambourg, Germany, 21-24 August 2016; p. 9.

15. European Parliament Directive 2002/49/EC of the European Parliament and of the Council of 25 June 2002 Relating to the Assessment and Management of Environmental Noise; European Parliament and Council: Brussels, Belgium, 2002.

16. Europe's Coronavirus Lockdown Measures Compared. Available online: https://www.politico.eu/article/ europes-coronavirus-lockdown-measures-compared/ (accessed on 15 May 2020).

17. Sicilia, M.; García-Barriocanal, E.; Sánchez-Alonso, S. Community Curation in Open Dataset Repositories: Insights from Zenodo. Procedia Comput. Sci. 2017, 106, 54-60. [CrossRef]

18. Yu, C.; Kang, J. Soundscape in the sustainable living environment: A cross-cultural comparison between the UK and Taiwan. Sci. Total Environ. 2014, 482, 501-509. Available online: http://www.sciencedirect.com/ science/article/pii/S0048969713012515 (accessed on 15 May 2020). [CrossRef]

19. Sato, T.; Yano, T.; Björkman, M.; Rylander, R. Comparison of community response to road traffic noise in japan and sweden-Part i: Outline of surveys and dose-response relationships. J. Sound Vib. 2002, 250, 161-167. Available online: http://www.sciencedirect.com/science/article/pii/S0022460X01938921 (accessed on 15 May 2020). [CrossRef]

20. European Comission. European Comission Position Paper on EU Noise Indicators; European Comission: Brussels, Belgium, 2000. 
21. Gozalo, G.R.; Carmona, J.T.; Morillas, J.B.; Vílchez-Gómez, R.; Escobar, V.G. Relationship between objective acoustic indices and subjective assessments for the quality of soundscapes. Appl. Acoust. 2015, 97, 1-10. [CrossRef]

22. Alberola, J.M.; Flindell, I.H.; Bullmore, A.J. Variability in road traffic noise levels. Appl. Acoust. 2005, 66, 1180-1195. [CrossRef]

23. Nelson, P. Transportation Noise Reference Book; Butterworths: London, UK, 1987.

24. Can, A.; Gauvreau, B. Describing and classifying urban sound environments with a relevant set of physical indicators. J. Acoust. Soc. Am. 2015, 137, 208-218. [CrossRef] [PubMed]

25. Axelsson, O.; Nilsson, M.E.; Berglund, B. A principal components model of soundscape perception. J. Acoust. Soc. Am. 2010, 128, 2836-2846. [CrossRef] [PubMed]

26. Gontier, F.; Lavandier, C.; Aumond, P.; Lagrange, M.; Petiot, J.F. Estimation of the perceived time of presence of sources in urban acoustic environments using deep learning techniques. Acta Acust. United Acust. 2019, 105, 1053-1066. [CrossRef]

27. Aumond, P.; Can, A.; Coensel, B.D.; Botteldooren, D.; Ribeiro, C.F.; Lavandier, C. Modeling soundscape pleasantness using perceptual assessments and acoustic measurements along paths in urban context. Acta Acust. United Acust. 2017, 103, 430-443. [CrossRef]

28. Torija, A.J.; Ruiz, D.P.; Ramos-Ridao, A.F. Application of a methodology for categorizing and differentiating urban soundscapes using acoustical descriptors and semantic-differential attributes. J. Acoust. Soc. Am. 2013, 134, 791-802. [CrossRef]

29. Ascari, E.; Licitra, G.; Teti, L.; Cerchiai, M. Low frequency noise impact from road traffic according to different noise prediction methods. Sci. Total Environ. 2015, 505, 658-669. [CrossRef]

30. Kjellberg, A.; Tesarz, M.; Holmberg, K.; Landström, U. Evaluation of frequency-weighted sound level measurements for prediction of low-frequency noise annoyance. Environ. Int. 1997, 23, 519-527. [CrossRef]

31. Cik, M.; Lienhart, M.; Lercher, P. Analysis of Psychoacoustic and Vibration-Related Parameters to Track the Reasons for Health Complaints after the Introduction of New Tramways. Appl. Sci. 2016, 6, 398. [CrossRef]

32. Leventhall, H. Low frequency noise and annoyance. Noise Health 2004, 6, 72.

33. DIN. DIN 45680: 2013 Measurement and Assessment of Low-frequency Noise Immissions in the Neigbourhood; DIN: Berlin, Germany, 2013.

34. Janssen, S.A.; Centen, M.R.; Vos, H.; van Kamp, I. The effect of the number of aircraft noise events on sleep quality. Appl. Acoust. 2014, 84, 9-16. [CrossRef]

35. Gasco, L.; Asensio, C.; de Arcas, G. Communicating airport noise emission data to the general public. Sci. Total Environ. 2017, 586, 836-848. [CrossRef] [PubMed]

36. Dutilleux, G.; Gjestland, T.T.; Licitra, G. Challenges of the Use of Sound Emergence for Setting Legal Noise Limits. Int. J. Environ. Res. Public Health 2019, 16, 4517. [CrossRef] [PubMed]

37. Bockstael, A.; De Coensel, B.; Lercher, P.; Botteldooren, D. Influence of temporal structure of the sonic environment on annoyance. In 10th International Congress on Noise as a Public Health Problem (ICBEN-2011); Griefahn, B., Ed.; Institute of Acoustics: London, UK, 2011; pp. 945-952.

38. Lercher, P.; Bockstael, A.; De Coensel, B.; Dekoninck, L.; Botteldooren, D. The application of a notice-event model to improve classical exposure-annoyance estimation. J. Acoust. Soc. Am. 2012, 131, 3223. [CrossRef]

39. Lercher, P.; Coensel, B.D.; Dekonink, L.; Botteldooren, D. Community Response to Multiple Sound Sources: Integrating Acoustic and Contextual Approaches in the Analysis. Int. J. Environ. Res. Public Health 2017, 14, 663. [CrossRef]

40. Lercher, P.; Coensel, B.D.; Dekoninck, L.; Botteldooren, D. Alternative traffic noise indicators and its association with hypertension. In Proceedings of the 11th European Congress and Exposition on Noise Control Engineering (Euronoise 2018), EEA and Greek Acoustical Society Hersonissos, Crete, Greece, 27-31 May 2018; pp. 457-464.

41. Nilsson, M.E.; Botteldooren, D.; Coensel, B.D. Acoustic indicators of soundscape quality and noise annoyance in outdoor urban areas (invited paper). In 19th International Congress on Acoustics; Instituto de Acústica: Madrid, Spain, 2007.

42. Lercher, P.; Pieren, R.; Wunderli, J.M. Noise and hypertension: Testing alternative acoustic indicators. In Proceedings of the 23rd International Congress on Acoustics, ICA 2019, Aachen, Germany, 9-13 September 2019. 
43. Héritier, H.; Vienneau, D.; Foraster, M.; Eze, I.C.; Schaffner, E.; Thiesse, L.; Ruzdik, F.; Habermacher, M.; Köpfli, M.; Pieren, R.; et al. Diurnal variability of transportation noise exposure and cardiovascular mortality: A nationwide cohort study from Switzerland. Int. J. Hyg. Environ. Health 2018, 221, 556-563. [CrossRef] [PubMed]

44. Brink, M.; Schäffer, B.; Vienneau, D.; Foraster, M.; Pieren, R.; Eze, I.C.; Cajochen, C.; Probst-Hensch, N.; Röösli, M.; Wunderli, J. A survey on exposure-response relationships for road, rail, and aircraft noise annoyance: Differences between continuous and intermittent noise. Environ. Int. 2019, 125, 277-290. [CrossRef] [PubMed]

45. Wunderli, J.M.; Pieren, R.; Habermacher, M.; Vienneau, D.; Cajochen, C.; Probst-Hensch, N.; Röösli, M.; Brink, M. Intermittency ratio: A metric reflecting short-term temporal variations of transportation noise exposure. J. Expo. Sci. Environ. Epidemiol. 2016, 26, 575. [CrossRef] [PubMed]

46. Salamon, J.; Bello, J.P. Unsupervised feature learning for urban sound classification. In Proceedings of the 2015 IEEE International Conference on Acoustics, Speech and Signal Processing (ICASSP), Brisbane, QLD, Australia, 19-24 April 2015; pp. 171-175.

47. Socoro, J.C.; Alías, F.; Pages, R.M.A. An Anomalous Noise Events Detector for Dynamic Road Traffic Noise Mapping in Real-Life Urban and Suburban Environments. Sensors 2017, 17, 2323. [CrossRef] [PubMed]

48. Gloaguen, J.; Can, A.; Lagrange, M.; Petiot, J. Road traffic sound level estimation from realistic urban sound mixtures by Non-negative Matrix Factorization. Appl. Acoust. 2019, 143, 229-238. [CrossRef]

49. ISO. ISO/TS 12913-2:2018 Acoustics—Soundscape-Part 2: Data Collection and Reporting Requirements; ISO: Geneva, Switzerland, 2018.

50. Mitchell, A.; Oberman, T.; Aletta, F.; Erfanian, M.; Kachlicka, M.; Lionello, M.; Kang, J. The Soundscape Indices (SSID) Protocol: A Method for Urban Soundscape Surveys-Questionnaires with Acoustical and Contextual Information. Appl. Sci. 2020, 10, 2397. [CrossRef]

(C) 2020 by the authors. Licensee MDPI, Basel, Switzerland. This article is an open access article distributed under the terms and conditions of the Creative Commons Attribution (CC BY) license (http://creativecommons.org/licenses/by/4.0/). 